Jurnal Ilmu Keolahragaan Volume III Nomor 2 Oktober 2020

Nur'Aenon. I Iskandar, Hendriana Sri Rejeki

Tersedia di: http://jurnal.untan.ac.id/index.php/jilo

\title{
FAKTOR FAKTOR YANG MEMPENGARUHI RENDAHNYA PRESTASI BELAJAR PENDIDIKAN JASMANI
}

\author{
Nur'Aenon. I Iskandar, Hendriana Sri Rejeki* \\ Program Studi Pendidikan Jasmani dan Rekreasi, Universitas Tadulako \\ Coresspondensi author, email: hendriana@untad.ac.id
}

\begin{abstract}
Abstrak
Permasalahan dalam penelitian ini rendahnya prestasi belajar pendidikan jasmani. Belum diketahui penyebab rendahnya prestasi belajar pendidikan jasmani. Tujuan penelitian ini adalah untuk mengetahui faktor-faktor yang menyebabkan rendahnya prestasi belajar pendidikan jasmani pada siswa kelas IV SDN 8. Populasi penelitian ini adalah seluruh siswa kelas IV SDN 8 Mamboro yang ada di Kecamatan Palu Utara. Sampel adalah 40 siswa kelas IV SDN 8 Kecamatan Palu Utara. Instrumen Penelitian menggunakan lembar observasi, angket, wawancara serta disertai dengan dokumentasi. Hasil penelitian menunjukka bahwa beberapa faktor penyebab rendahnya prestasi belajar pendidikan jasmani Utara antara lain berasal dari 1) faktor internal anak didik, 2) Kurangnya fasilitas belajar pendidikan jasmani dan adanya faktor lingkungan sekolah, 3) faktor dari lingkungan sekolah, 4) faktor dari guru, 5) faktor dari lingkungan keluarga.
\end{abstract}

Kata Kunci: Pendidikan Jasmani, Prestasi Belajar

\section{FACTORS AFFECTING \\ LOW PHYSICAL EDUCATION LEARNING ACHIEVEMENT}

\begin{abstract}
The problem in this study is the low learning achievement of physical education. It is not yet known the cause of the low learning achievement of physical education. The purpose of this study was to determine the factors that caused the low learning achievement of physical education in grade IV SDN 8. The population of this study was all fourth-grade students of SDN 8 Mamboro in the North Palu District. The sample was 40 fourth grade students of SDN 8 North Palu District. Research instruments using observation sheets, questionnaires, interviews, and accompanied by documentation. The results showed that some of the factors causing the low learning achievement of North physical education, among others, came from 1) internal factors of students, 2) lack of physical education learning facilities and the existence of school environmental factors, 3) factors from the school environment, 4) factors from the teacher, 5) factors from the family environment.
\end{abstract}

Keywords: Physical education, Achievement Factors 
Tersedia di: http://jurnal.untan.ac.id/index.php/jilo

\section{PENDAHULUAN}

Pendidikan jasmani adalah suatu proses melalui aktivitas jasmani, yang dirancang dan disusun secara sistematik, untuk merangsang pertumbuhan dan perkembangan, meningkatkan kemampuan dan keterampilan jasmani, kecerdasan dalam pembentukan watak, serta nilai sikap yang positif bagi setiap warga Negara dalam rangka mencapai tujuan pendidikan.

Tujuan pendidikan jasmani di SD adalah memacu kepada pertumbuhan dan perkembangan jasmani, mental, emosional dan sosial yang selaras dalam upaya membentuk dan mengembangkan kemampuan gerak dasar, menanamkan nilai, sikap dan membiasakan hidup sehat.

Pelaksanaan proses pembelajaran pendidikan jasmani di sekolah, guru selalu menghadapi anak didik dengan tingkat kecakapan/intelegensi, perhatian, minat, bakat ataupun kesiapan dalam menerima pelajaran yang berbeda-beda. Akan tetapi guru dalam memberikan pengajaran tidak memperhatikan hal-hal tersebut di atas, ia mengajar dan menerapkan pola dan metode yang sama antara keduanya berbeda. Dengan demikian akan timbul suatu masalah dalam diri anak didik yaitu masalah kesulitan belajar pada peserta didik.

Kendala yang kemungkinan menjadi kendala dalam pendidikan jasmani yaitu, kurikulum, factor internal, kekurangan bahan/fasilitas, minimnya motovasi dari orang tua. Beberapa hal ini kemungkinan menjadikan pendidikan jasmani kurang optimal. Perhatian orang tua, motivasi belajar berpengaruh terhadap prestasi belajar siswa (Mawarsih, Susilaningsih and Hamidi, 2013). ternyata perlakuan dan sikap orang tua, guru kepada peserta didik berpengaruh terhadap hasil belajar siswa (Simbolon, 2014). Berdasarkan pada penelitian ini dapat dipahami bahwa orang tua memberikan pengaruh yanb besar terhadap prestas belajar siswa.

Berikutnya adalah dari faktor guru, pemahaman guru terhadap kurikulum level dokumen dan implementasinya terkadang ada gap yang jauh. Lingkungan belajar yang baik akan menghasilkan hasil belajar yang baik (Hendarwati, 2013), metode inkuiri lebih baik dibandingkan dengan ceramah (Hendarwati, 2013) terhadap hasil belajar siswa. Berdasarkan pada penelitian ini dapat diambil simpulan bahwa guru merupakan sosok yang menjadi center dalam prose belajar mengajar. Pemilihan metode yang tepat akan menentukan keberhasilan dalam belajar. Metode yang tidak tepat terdadap peserta didik, materi dan kesesuaian kurikulum akan menghambat proses pembelajaran yang bermuara pada hasil pembelajaran. Pemahaman ini masih lagi terkendala dengan keterbatasan sarana dan prasaranan penunjang kegiatan. Pada dua bagian berikutnya adalah dukungan serta motivasi dari individu untuk melaksanakan pendidikan jasmani dengan baik . tidak dipungkiri bahwa pelaksanaan pendidikan jasmani dengan menggunakan olahraga, sehingga diperlukan dukungan dari orang tua untuk pemenuhannya.

Berdasarkan pengamatan peneliti di kelas ditampak bahwa dari sekian banyak anak didik yang dihadapi, ada beberapa anak didik yang berhasil dalam belajarnya. Ada yang sedang-sedang saja dan ada pula yang kurang karena mengalami hambatan atau mengalami kesulitan belajar. Bentukbentuk kesulitan itu berbagai macam, ada yang sederhana dan ada pula yang rumit sehingga baik secara individu ataupun klasikal memerlukam penanganan yang serius. Oleh karena itu, apabila proses pembelajaran pendidikan jasmani yang diselenggarakan di SD, baik pertumbuhan dan perkembangan jasmani maupun rohani yang harmonis, sehingga anak didik dapat belajar dengan baik serta membantu dalam peningkatan prestasi belajar yang maksimal.

Anak didik yang merasa bosan untuk mengikuti mata pelajaran pendidikan jasmani sehingga ia tidak mengikuti pelajaran tersebut dengan baik, maka ia 


\section{Jurnal Ilmu Keolahragaan Volume III Nomor 2 Oktober 2020 \\ Nur'Aenon. I Iskandar, Hendriana Sri Rejeki \\ Tersedia di: http://jurnal.untan.ac.id/index.php/jilo}

termasuk anak didik yang mengalami kesulitan dalam belajar. Motivasi berpengaruh terhadap hasil belajar IPA di sekolah dasar (Pratama, Firman, \& Neviyarni, 2019), Penelitian ini memberikan gambaran bahaw siswa yang termotivasi belajar akan lebih berhasil. Tidak akan terjadi kebosanan bagi siswa yang memiliki motivasi untuk belajar.

Pada dasarnya terdapat faktor internal dan eksternal yang berpengaruh terhadap hasil belajar. Kedua faktor ini saling mempengaruhi psikologis dan fisiologis (internal), lingkungan, sosial, metode pembelajaran yang dipertunakan, lingkungan sekolah, lingkungan sekitar (eksternal) (Utami, 2016). Faktor faktro ini menjadikan variabel yang perlu dicermati agar keberhasilan pembelajaran yang ditunjukkan dengan ketuntasan belajar dapat terjamin.

Masih perlu diselediki sebenarnya pada bagian mana yang menjadi penyebab terjadinya permasalahan yang menghambat capaian belajar dalam pendidikan jasmani. Data ini sangat penting, apabila hal tersebut tidak segera diantisipasi sedini mungkin akibatnya akan mengarah pada timbulnya dampak negatif peningkatan mutu kualitas pendidikan pelajaran pendidikan jasmani di SDN 8 Mamboro.

\section{METODE}

Jenis penelitian yang digunakan dalam penelitian ini adalah penelitian deskriptif Nawawi dan Martini (1996). Karena itu, penggunaan metode deskriptif dalam penelitian ini bertujuan untuk mendapatkan gambaran yang jelas mengenai masalah yang diteliti dan dianalisis secara deskriptif. Penelitian dilaksanakan di SDN 8 Mamboro Kecamatan Palu Utara tepatnya di kelas IV dengan 40 sampel siswa. Data dikumpulkan dengan observasi, angket, wawancara dan dokumentasi. Data dianalisis dengan deskriptif. Ada data yang sifatnya kualtiatif dan khusus data kuantiatif dianalisis dengan deskriptif kuantitatif.

\section{HASIL}

Penelitian ini diawali dengan memberikan angket kepada masing-masing siswa. siswa laki-laki dan siswa perempuan. Jumlah pertanyaan dalam angket 14 pertanyaan yang dimana sudah di siapkan dan dibagi dalam 4 kelompok pertanyaan yang disesuaikan dengan faktor-faktor yang mempengaruhi rendahnya prestasi belajar pendidikan jasmani, yakni faktor rendahnya prestasi belajar pendidikan jasmani yang ditinjau dari faktor internal (dari dalam diri) siswa, lingkungan sekolah, lingkungan keluarga, dan faktor guru sendiri.

Sesuai hasil penyebaran angket diperoleh data sebagai hasil penelitian yang dirangkum pada tabel 1 diketahui bahwa 35 siswa $(87,5 \%)$ anak didik mempunyai minat yang cukup tinggi dalam belajar dan 5 siswa $(32,5 \%)$ anak didik lainnya menyatakan sebaliknya. Selanjutnya, sebanyak 22 siswa $(55 \%)$ anak didik mempunyai daya serap/kemampuan belajar yang bagus dan 18 siswa(45\%) lainnya masih dibawah ratarata. Demikian pula halnya dengan keseriusan/perhatian anak didik dalam belajar. Dari table 1 tersebut juga diperoleh informasi bahwa sebanyak 27 siswa $(67,5 \%)$ anak didik serius/punya perhatian dalam belejar dan 13 orang (32,5\%) lainnya belum memiliki kesriusan/perhatian dalam belajar seperti yang diharapkan.

Dari hasil obeservasi diperoleh data bahwa keseriusan siswa dalam belajar baik di dalam belajar cukup tinggi. Namun, kemampuan anak didik dalam menjawab pertanyaan dari guru serta adanya perhatian selama pembeljaran masih tergolong dalam kategori cukup. Disisi lain, berdasarkan pengamatan ketika anak didik melakukan praktek ditemukan bahwa kemampuan anak didik melakukan praktek sudah tergolong baik.

Sedangkan berdasarkan hasil wawancara dengan beberapa siswa diperoleh data bahwa sebagian besar sangat 


\section{Jurnal Ilmu Keolahragaan Volume III Nomor 2 Oktober 2020 \\ Nur'Aenon. I Iskandar, Hendriana Sri Rejeki \\ Tersedia di: http://jurnal.untan.ac.id/index.php/jilo}

menyukai pelajaran pendidikan jasmani. Hal ini menunjukkan bahwa minat yang sangat tinggi dalam belajar. Akan tetapi hal ini tidak diikuti dengan motivasi yang tinggi dari dalam belajar.

Berdasarkan hasil penelitian dapat dilakukan bahwa minat anak didik dalam belajar cukup bagus. Akan tetapi belum disertai dengan adanya perhatian yang baik dari anak didik dalam belajar sehingga mengakibatkan kemampuan atau daya serap terhadap pelajaran masih rendah.

Tabel. 1 Hasil Angket Yang Diberikan Ke Siswa.

\begin{tabular}{lcccc}
\multirow{2}{*}{ Rendahnya Prestasi Belajar } & \multicolumn{2}{c}{$\begin{array}{c}\text { Siswa yang Menjawab } \\
\text { Pertanyaan (F) }\end{array}$} & \multicolumn{2}{c}{$\begin{array}{c}\text { Persentase Jawaban } \\
\text { Siswa (P) }\end{array}$} \\
\cline { 2 - 5 } & Ya & Tidak & Ya & Tidak \\
\hline Minat siswa untuk belajar & 35 Siswa & 5 Siswa & $87,5 \%$ & $32,5 \%$ \\
\hline $\begin{array}{l}\text { Kemampuan/daya serap } \\
\text { siswa }\end{array}$ & 22 Siswa & 18 Siswa & $55 \%$ & $45 \%$ \\
Perhatian siswa belajar & 27 Siswa & 13 Siswa & $67,5 \%$ & $32,5 \%$ \\
\hline
\end{tabular}

Sesuai dengan tabel 2 dapat dilihat bahwa fasilitas belajar penjaskes dan penggunaannya dalam pembelajaran oleh guru serta suasana belajar masih jauh dari diharapkan. Pada tabel 2 tersebut diketahui bahwa 31 orang $(77,5 \%)$ anak didik menganggap bahwa kelengkapan fasilitas belajar penjaskes di sekolah masih sangat minim dan 9 siswa $(22,5 \%)$ anak didik lainnya berpendapat sebaliknya. Selain itu, 33 siswa $(82,5 \%)$ anak didik berpendapat bahwa guru masih jarang menggunakan fasilitas belajar penjaskes di sekolah dan hanya 7 siswa $(17,5 \%)$ anak didik beranggapan sebaliknya. Sedangkan sebanyak 22 siswa (55\%) anak didik beranggapan bahwa suasana pembelajaran di kelas belum optimal dan 18 siswa (45\%) lainnya menganggap telah optimal.

Sementara itu, jika mengacu pada hasil wawancara dengan anak didik diperoleh data bahwa suasana belajar di sekolah masih kurang nyaman. Pada waktu jam pelajaran berlangsung. Beberapa warga sekitar sekolah masih sering memutar tape keras sehingga mengganggu jalannya proses pembelajaran. Selain hal tersebut, juga diperoleh informasi bahwa fasilitas belajar pendidikan jasmani di sekolah masih sangat kurang.

Bertolak dari fakta tersebut, diperoleh gambaran bahwa kelengkapan fasilitas belajar penjaskes dan suasana lingkungan sekolah masih sangat berpengaruh terhadap munculnya kesulitan belajar bagi siswa.

Tabel 2. Persentase Hambatan Belajar

Dari Factor Sarana Prasarana Dan Lingkungan

\begin{tabular}{lcccc}
\hline \multicolumn{1}{c}{$\begin{array}{c}\text { Faktor Penyebab } \\
\text { Kesulitan Belajar Siswa }\end{array}$} & \multicolumn{2}{c}{$\begin{array}{c}\text { Jumlah Siswa yang } \\
\text { Menjawab Pertanyaan (F) }\end{array}$} & \multicolumn{2}{c}{$\begin{array}{c}\text { Persentase Jawaban } \\
\text { Siswa (P) }\end{array}$} \\
\cline { 2 - 5 } & Ya & Tidak & Ya & Tidak \\
\hline $\begin{array}{l}\text { Kelengkapan fasilitas } \\
\text { belajar Penjaskes di } \\
\text { sekolah }\end{array}$ & 9 Siswa & 31 Siswa & $227,5 \%$ & $77,5 \%$ \\
\hline $\begin{array}{l}\text { Penggunaan fasilitas } \\
\text { belajar penjaskes oleh } \\
\text { guru }\end{array}$ & 7 Siswa & 33 Siswa & & \\
Suasana Belajar & & & & \\
\hline
\end{tabular}




\section{Jurnal Ilmu Keolahragaan Volume III Nomor 2 Oktober 2020 \\ Nur'Aenon. I Iskandar, Hendriana Sri Rejeki \\ Tersedia di: http://jurnal.untan.ac.id/index.php/jilo}

Mengacu pada tabel 3 diperoleh gambaran data bahwa sebagian besar anak didik atau 21 siswa $(52,5 \%)$ menganggap dalam penyajian materi pembelajaran, guru telah dapat menjelaskan dengan baik konsep yang diajarkan. Akan tetapi hal tersebut tidak diikuti dengan cara guru dalam melakukan bimbingan kepada anak didik saat pembelajaran berlangsung. Sebanyak 23 siswa $(57,5 \%)$ anak didik menganggap bahwa guru masih kurang melakukan bimbingan yang baik kepada anak didik belajar dan 17 siswa anak didik lainnya berpendapat sebaliknya. Sementara itu, sebanyak 27 siswa $(67,5 \%)$ anak didik berpendapat bahwa sikap guru dalam mengajar yang disertai dengan cara pemberian kesempatan bertanya kepada anak didik masih rendah member kesempatan bagi mereka untuk bertanya dalam kegiatan pembelajaran sudah baik.

Dari hasil observasi diperoleh data bahwa kemampuan guru dalam menyampaikan materi pelajaran sudah sangat baik. Namun, jika dilihat dari kemampuan mengelola kelas, membimbing anak didik selama proses pembelajaran, bersikap ramah, penyayang dan tidak pemarah serta kemampuan memotivasi anak didik masih tergolong cukup. Ini menunjukkan bahwa guru masih perlu meningkatkan kemampuannya dalam mengelola kelas. Karena berdasarkan data tersebut dapat disimpulkan bahwa guru juga ikut mempengaruhi timbulnya kesulitan belajar bagi anak didik.

Sedangkan berdasarkan hasil wawancara beberapa dengananak didik juga diperoleh data yang sama. Hamper semua anak didik menganggap bahwa penjelasan materi yang diberikan oleh guru mudah mereka ikuti. Akan tetapi sepeti yang telah diuaraikan sebelumnya. Guru masih kurang membimbing dan member motivasi kepada mereka ketika mendapatkan kesulitan dalam belajar. Selain itu, sebagian besar anak didik juga masih merasa takut terhadap guru pendidikan jasmani karena masih sering bersikap kurang ramah, dan sering marah.

Berdasarkan data tersebut diperoleh gambaran bahwa guru telah menguasai materi dengan baik tetapi bellum dibarengi dengan mengoptimalkan teknik mengajar yang lain seperti melakukan proses bimbingan saat pelajaran berlangsung, member kesempatan bertanya yang lebih kapada anak didik serta menampilkan sikap yang pernah dan tidak menakutkan kepada anak didik.

Tabel 3 Persentase Hambatan Belajar Dari Faktor Guru

\begin{tabular}{|c|c|c|c|c|}
\hline \multirow[t]{2}{*}{$\begin{array}{l}\text { Cara Guru dalam } \\
\text { Mengajar Siswa }\end{array}$} & \multicolumn{2}{|c|}{$\begin{array}{c}\text { Jumlah Siswa yang Menjawab } \\
\text { Pertanyaan (F) }\end{array}$} & \multicolumn{2}{|c|}{$\begin{array}{c}\text { Persentase Jawaban } \\
\text { Siswa (P) }\end{array}$} \\
\hline & Ya & Tidak & Ya & Tidak \\
\hline Penguasaan Materi & 21 Siswa & 19 Siswa & $52,5 \%$ & $47,5 \%$ \\
\hline $\begin{array}{l}\text { Bimbingan Terhadap } \\
\text { Siswa }\end{array}$ & 17 Siswa & 23 Siswa & $42,5 \%$ & $57,5 \%$ \\
\hline Sikap Guru & 13 Siswa & 27 Siswa & $32,5 \%$ & $67,5 \%$ \\
\hline Kesempatan Bertanya & 13 Siswa & 27 Siswa & $32,5 \%$ & $67,5 \%$ \\
\hline
\end{tabular}

Sesuai dengan tabel 4. diperoleh data bahwa sebagian besar siswa menganggap fasilitas belajar dirumah, motivasidan bimbingan dari orang tua serta teman belajar di rumahbagi mereka sangat berpengaruh terhadap munculnya kesulitan belajar mereka. Dari tabel4 tersebut diperoleh bahwa 26 siswa (65\%) anak didik berpendapat fasilitas belajar dirumahnya masih minim 29 siswa $(73,5 \%)$ anak didik dan 32 siswa (80\%) anak didik menganggap bahwa motivasi dan bimbingan dari orang tua masih sangat kurang. Selain itu sebagian besar anak didik juga masih sangat kurang untuk melakukan belajar kelompok dirumah.

Melalui hasil wawancara dengan anak didik diketahui bahwa motivasi 


\section{Jurnal Ilmu Keolahragaan Volume III Nomor 2 Oktober 2020 \\ Nur'Aenon. I Iskandar, Hendriana Sri Rejeki \\ Tersedia di: http://jurnal.untan.ac.id/index.php/jilo}

mereka untuk belajar di rumah masih sangat kurang. Hal ini disebabkan karena kurangnya fasilitas belajar yang ada dirumah serta kurangnya motivasi dan bimbingan dari orang tua untuk belajar. Dari hasil wawancara tersebut, masih ditemukan anak didik yang mengaku bahwa orang tuanya lebih memotivasi anaknya untuk belajar mata pelajaran lain dibanding belajar pendidikan jasmani.

Bertolak dari paparan data tersebut diperoleh gambaran bahwa keluarga atau lingkungan masyarakat sangat berpengaruh terhadap munculnya tingkat kesulitan belajar bagi anak didik.

\begin{tabular}{|c|c|c|c|c|}
\hline \multirow[t]{2}{*}{$\begin{array}{c}\text { Faktor Penyebab } \\
\text { Kesulitan Belajar } \\
\text { Siswa }\end{array}$} & \multicolumn{2}{|c|}{$\begin{array}{c}\text { Jumlah Siswa yang } \\
\text { Menjawab Pertanyaan } \\
\text { (F) }\end{array}$} & \multicolumn{2}{|c|}{$\begin{array}{c}\text { Persentase Jawaban } \\
\text { Siswa }(\mathbf{P})\end{array}$} \\
\hline & Ya & Tidak & Ya & Tidak \\
\hline $\begin{array}{l}\text { Fasilitas belajar } \\
\text { dirumah }\end{array}$ & 14 Siswa & 26 Siswa & $35 \%$ & $65 \%$ \\
\hline $\begin{array}{l}\text { Motivasi dari orang } \\
\text { tua }\end{array}$ & 11Siswa & 29 Siswa & $27,5 \%$ & $73,5 \%$ \\
\hline $\begin{array}{l}\text { Bimbingan dari orang } \\
\text { tua }\end{array}$ & 8 Siswa & 32 Siswa & $20 \%$ & $80 \%$ \\
\hline Teman belajar & 11 Siswa & 29 Siswa & $27,5 \%$ & $73,5 \%$ \\
\hline
\end{tabular}

Upaya yang dilakukan oleh guru dalam mengatasi kesulitan anak didik dalam belajar pendidikan jasmani cukup beragam. Akan tetapi, berdasarkan informasi yang diperoleh melalui wawancara dengan guru pendidikan jasmani pada sekolah dan kelas yang dijadikan sampel penelitian ini antara lain meliputi: Pemberi Motivasi Kepada Anak Didik

Dalam hal pemberian motivasi, guru memegang peranan penting sebagai elemen utama dalam mengatasi kesulitan belajar anak didik. Pemberian motivasi yang dilakukan oleh guru berpegang teguh kepada bagaimana cara mengatasi kesulitan belajar anak didik ditinjau dari faktor internal anak didik dan dari faktor guru itu sendiri.

Guru pendidikan jasmani seyogyanya member motivasi kepada anak didik dengan cara memperbaiki dan meningkatkan teknik atau metode mengajar bervariasi yang lebih menekankan kepada pemberian perhatian penuh dalam hal menunjukkan sikap yang ramah kepada anak didik yang dibarengi dengan penggunaan teknik membimbing dan mengelola kelas yang lebih efektif dan efesien.

Sekolah sebagai penyelenggara pendidikan harus dapat berperan bersama warga komite sekolah untuk melenngkapi sarana dan prasarana olahraga di sekolahnya masing-masing. Dengan adanya sarana olahraga yang memadai diharapkan kondisi pembelajaran pendidikan jasmani di sekolah akan semakin baik sesuai dengan apa yang diharapkan.

Selain menjalin kerjasama dengan komite. Sekolah juga harus dapat menjalin kerjasama yang baik dengan orang tua anak didik agar lebih berperan aktif dalam membimbing. Memotivasi serta melakukan control kepada masing-masing anaknya demi peningkatan kualitas mutu pendidikan. Dengan dilakukannya hal tersebut diharapkan kesulitan hal tersebut diharapkan kesulitan belajar anak didik dapat diatasi.

\section{PEMBAHASAN}

Sebagaimana telah dikemukakan sebelumnya bahwa ada empat faktor yang 


\section{Jurnal Ilmu Keolahragaan Volume III Nomor 2 Oktober 2020 \\ Nur'Aenon. I Iskandar, Hendriana Sri Rejeki \\ Tersedia di: http://jurnal.untan.ac.id/index.php/jilo}

mempengaruhi kesulitan belajar bagi anak didik, yakni faktor internal atau faktor dari dalam diri anak didik, faktor lingkungan sekolah/sarana sekolah, faktor guru dan faktor lingkungan keluarga.

\section{Faktor Internal Anak Didik}

Sesuai dengan data yang diperoleh, minat anak didik untuk mengikuti pelajaran pendidikan jasmani pada dasarnya cukup tinggi. Hal ini dilihat dari besarnya persentase anak didik yang menjawab sangat berminat dalam belajar, yakni sebesar $87,5 \%$. Kenyataan ini di dukung oleh hasil penelitian yang menyatakan bahwa motivasi berprestasi berpengaruh terhadap hasil belajar, kedua persepsi siswa terhadap guru memiliki pengaruh positif terhadap hasil belajar (Latief \& Jamil, 2017). Motivasi dan persepsi media pembelajaran berpengaruh terhadap hasil belajar siswa (Sutrisno and Siswanto, 2016a). berdasarkan pada pendapat ini sejalan dangan hasil penelitian. DIlihat dari sudut pandang internal siswa ternyata tidak terjadipermasalaha. Namun dengan hasil belajar yang masih rendah dapat dipahami bukan dari internal siswa. Terlebih menurut peneliti menyatakan bahwa IQ dan motivasi berpengaruh bersar terhadap hasil belajar (Kadek \& Arini, 2012). Dipastikan bahwa kelas pasti dalam kondisi majemuk, sehingga akan terdapat perbedaan dari setiap siswa dalam kemampuan IQ yang akan berimbas pada proses dan hasil belajar.

Penelitian ini menerumkan bahwa variabel minat siswa tinggi, hal ini dibuktikan dengan pada kenyataan siswa di SD masih senang menghabiskan waktunya untuk bermain. IQ dan motivasi berpengaruh bersar terhadap hasil belajar (Kadek \& Arini, 2012). Motivasi menyumbang $48.1 \%$ terhadap prestasi belajar siswa sekolah dasar (Hamdu \& Agustina, 2011). Sementara penyajian materi pelajaran pendidikan jasmani sebagian besar dalam bentuk kelompok anak didik sangat berminat untuk belajar. Karenanya guru pendidikan jasmani hendaknya dapat memperhatikan dan memahami betul kondisi anak didik seperti ini agar anak didik tidak berkurang dalam belajar.

\section{Faktor Fasilitas Belajar Penjaskes dan Faktor Lingkungan Sekolah}

Mengacu pada data yang diperoleh di lapangan diperoleh informasi bahwa fasilitas belaja penjaskes di sekolah serta faktor dari lingkungan sekolah masih sangat berpengaruh terhadaptimbulnya kesulitan belajar bagi anak didik. Kurangnya fasilitas belajar penjaskes yang mendukung disekolah akan menyebabkan kegiatan pembelajaran tidak dapat berjalan efektif sebagaimana yang di inginkan. Selain itu, suasana pembelajaran yang dipengaruhi oleh faktor lingkungan sekitar sekolah masih sangat berpengaruh terhadap timbulnya kesulitan belajar anak didik. Lingkungan sekolah, manajemen kepala sekolah keinginan berprestasi pada guru berkontribusi terhadap prestasi belajar siswa (Jamali \& Prasojo, 2013). Lingkungan kerja, motovasi, disiplin kerja berpengaruh terhadap prestasi kerja pegawai (Sidanti, 2015).

Belum terpenuhi fasilitas belajar penjaskes di SDN 8 Mamboro Kecamatan Palu Utara merupakan salah satu faktor yang perlu diperhatikan oleh pihak sekolah maupun pemerintah. Sekolah melalui Komite sekolah Seyogyanya dapat memperhatikan hal tersebut guna pemenuhan fasilitas belajar penjaskes yang memadai. Demikian pula halnya bagi pemerintah, kiranya dapat mengalokasikan anggaran pembangunan dan pemenuhan terhadap kelengkapan fasilitas belajr penjaskes bagi sekola-sekolah yang belum lengkap fasilitas belajarnya.

Terkait dengan belum maksimalnya suasana pembelajaran pendidikan jasmani di kelas maupun di luar kelas, hal ini disebabkan karena lokasi SDN 8 Mamboro Kecamatan Palu Utara sangatlah kurang memadai dan di apit pemukiman penduduk yang padat. Pihak sekolah diharapkan dapat mengundang warga masyarakat sekitar 


\section{Jurnal Ilmu Keolahragaan Volume III Nomor 2 Oktober 2020 \\ Nur'Aenon. I Iskandar, Hendriana Sri Rejeki \\ Tersedia di: http://jurnal.untan.ac.id/index.php/jilo}

sekolah untuk diberikan pemahaman agar selama jam efektif belajar berlangsung kiranya mereka dapat ikut menjaga suasana belajar sekolah menjadi aman dan tenteram. Selain itu, juga diperlukan keterampilan guru untuk dapat lebih efektif dalam mengelola kelas selama kegiatan pembelajaran berlangsung. Disisi lain, sekolah ataupun guru pendidikan jasmani yang bersangkutan dalam setiap penyajian materi baik di dalam maupun di luar kelas kiranya dapat memanfaatkan media yang ada di sekolah maupun dengan berinovasi membuat media belajar sendiri yang bertujuan agar anak didik dapat lebih mudah memahami materi yang diberikan.

\section{Faktor Guru}

Sebagaimana data yang diperoleh di lapangan bahwa sebagian besar anak didik menganggap guru dapat menyajikan materi pelajaran dengan baik. Pendapat ini bertolak belakang faktor berikutnya yakni tentang sikap guru dalam mengajar. Sebagian besar anak didik merasa guru dalam menyajikan materi belum memaksimalkan cara membimbing anak didik bila mengalami kesulitan. Selain itu, sikap guru dalam mengajar masih kurang ramah, baik hati, penyayang, masih menakutkan bagi sebagian besar anak didik serta masih kurang memberikan kesempatan bertanya kepada anak didik selama pembelajaran berlangsung.

Kondisi di atas disebabkan banyak faktor, salah satunya adalah teknik pengelolaan kelas oleh guru yang bersangkutan yang belum maksimal. Seyogyanya guru harus dapat menggunakan perpaduan berbagai ragam metode dalam mengajar agar anak didik tidak merasa bosan dalam belajar. Sebagaimana Hamalik (dalam Firdaus, 2005: 28) mengatakan bahwa "penggunaan metode belajar hendaknya bervariasi, artinya guru hendaknya menggunakan berbagai ragam metode sekaligus sehingga anak didik berkesempatan melakukan berbagai kegiatan belajar atau proses belajar sehingga mengembangkan aspek pola tingkah laku anak didik. Strategi pembelajaran yang dipergunakan oleh guru berpengaruh terhadap hasil belajar, sedangkan minata siswa tidak berpengaruh (Firmansyah, 2015). Gaya mengajar serta strategi pembelajaran berpengaruh terhadap hasil belajar siwa (Halim, 2012) . Persepsi media pembelajaran, metode mengajar, motivasi belajar dan penguasaan metode mengajar berpengaruh terhadap hasil belajar (Sutrisno and Siswanto, 2016b).

Selain teknik mengajar yang perlu bervariasi, seorang guru juga dituntut untuk dapat bersikap lebih mengenal anak didiknya. Dengan Lingkungan, hubungan dengan pengajar dan teman berpengaruh terhadap prestasi belajar (Naibaho et al., 2012). Lingkungan teman sebaya, disiplin belajar berpengaruh terhadap hasil belajar di perguruan tinggi (Tego Saputro, 2012).

Hal ini sesuai dengan pendapat Djumhur dan surya (dalam Firdaus. 2005: 30) menyatakan bahwa bimbingan belajar yang dilakukan oleh guru seperti cara mempelajari atau menggunakan buku pelajaran, cara belajar yang efesien dapat membantu dalam memecahkan kesulitankesulitan dalam mata pelajaran.

\section{Faktor Lingkungan/Keluarga.}

Berdasarkan data yang diperoleh diketahui bahwa sebagian besar anak didik SDN 8 Mamboro Kecamatan Palu Utara belum memiliki fasilitas belajar yang memadai dirumahnya. Orang tua dan guru bersikap kepada peserta didik mempengaruhi prestasi belajar siswa (Yuzarion, 2017). Selain itu, masih banyak ditemukan anak didik yang kurang dibimbing oleh orang tuanya dalam belajar di rumah. Ditemukan pula bahwa ada orang tua anak didik yang lebih memetingkan anaknya untuk belajar mata pelajaran lain dibanding pelajaran penjaskes. Beberapa faktor seperti tingkat kesehatan, kondisi fisiologi, tingkat IQ, minat, bakat, kematangan, perhatian, kesiapan, faktor keluaarga, sekolah, masyarakat dapat mempengaruhi belajar peserta didik (Nursyaidah, 2014). 


\section{Jurnal Ilmu Keolahragaan Volume III Nomor 2 Oktober 2020 \\ Nur'Aenon. I Iskandar, Hendriana Sri Rejeki \\ Tersedia di: http://jurnal.untan.ac.id/index.php/jilo}

Berpegang kepada hasil penelitian yangtelah diuraikan di atas, diketahui bahwa keluarga dan lingkungan sekitar merupakan salah satu faktor penyebab timbulnya kesulitan belajar bagi anak didik. Kurangnya fasilitas belajar di rumah. Seperti adanya buku bacaan yang menunjang, meja belajar dan alat-alat olahraga lainnya, pemberian motivasi oleh orang tua kepada anaknya dalam belajar baik secara perorangan maupun berkelompok dengan teman-temannya sangat mempengaruhi mnculnya kesulitan belajar bagi anak didik. Hal ini sejalan dengan pendapat Hartono (1994) "Orang tua dalam mendidik anak selain terdorong oleh naluri, juga terdorong oleh harapan dan cita-cita keberhasilan yang diinginkannya".

\section{KESIMPULAN}

Penelitian menjelaskan beberapa factor yang menyebabkan rendahnya hasil belajar pendidikan jasmani. Pertama factor internal siswa, dari factor ini sebanarnya bukan penghambat hasil penelitian menunjukkan siswa berminat terhadap pembelajaran pendidikan jasmani. Kedua adalah factor sarana dan prasarana yang kurang lengkap dan kurang mendukung, factor ini masih memerlukan perhatian dari sekolah. Ketiga faktor guru, kaitan dengan guru, perlu perubahan cara penyampaian pembelajaran yang lebih menarik dan yang terakhir adalah faktor lingkungan dan keluarga, orang tua lebih mementingkan anaknya untuk belajar mata pelajaran yang lain.

\section{DAFTAR PUSTAKA}

Firmansyah, D. (2015). Pengaruh Strategi Pembelajaran dan Minat Belajar Terhadap Hasil Belajar Matematika. Jurnal Pendidikan UNSIKA.

Halim, A. (2012). Pengaruh Strategi Pembelajaran dan Gaya Belajar Terhadap Hasil Belajar Fisika Siswa SMPN 2 Secanggang Kabupaten Langkat. Jurnal Tabularasa PPS
UNIMED.

Hamdu, G., \& Agustina, L. (2011). Pengaruh Motivasi Belajar Siswa Terhadap Prestasi Belajar IPA di Sekolah Dasar. Jurnal Penelitian Pendidikan.

Jamali, A., \& Prasojo, L. D. (2013). Pengaruh kompetensi manajerial kepala sekolah, lingkungan, motivasi guru, terhadap prestasi siswa SMA Muhammadiyah kota Yogyakarta. Jurnal Akuntabilitas Manajemen Pendidikan. https://doi.org/10.21831/amp.v1i1.23 09

Kadek, N., \& Arini, S. (2012). Pengaruh Tingkat Intelegensi Dan Motivasi Belajar Terhadap Prestasi Akademik Siswa Kelas Ii Sma Negeri 99 Jakarta. Jurnal Gunadarma.

Latief, S., \& Jamil, D. (2017). Pengaruh motivasi berprestasi dan persepsi siswa tentang cara guru mengajar terhadap hasil belajar matematika. Jurnal Pendidikan Matematika.

Pratama, F., Firman, F., \& Neviyarni, N. (2019). Pengaruh motivasi belajar siswa terhadap hasil belajar IPA di sekolah dasar. EDUKATIF: Jurnal Ilmu Pendidikan. https://doi.org/10.31004/edukatif.v1i3 .63

Sidanti, H. (2015). Pengaruh lingkungan kerja, disiplin kerja dan motivasi kerja terhadap kinerja pegawai negeri sipil di sekretariat dprd kabupaten madiun. Jurnal JIBEKA.

Sutrisno, V. L. P., \& Siswanto, B. T. (2016). Faktor-faktor yang mempengaruhi hasil belajar siswa pada pembelajaran praktik kelistrikan otomotif SMK di kota Yogyakarta. Jurnal Pendidikan Vokasi. https://doi.org/10.21831/jpv.v6i1.811 8

Tego Saputro, S. (2012). Pengaruh Disiplin Belajar Dan Lingkungan Teman Sebaya Terhadap Prestasi Belajar Mahasiswa Program Studi. Jurnal 
Tersedia di: http://jurnal.untan.ac.id/index.php/jilo

Pendidikan Akuntansi Indonesia Singgih Tego Saputro \& Pardiman Halaman.

Utami, P. S. (2016). Pengaruh gaya belajar dan metode pembelajaran terhadap hasil belajar IPS siswa SMP. Jurnal Dimensi Pendidikan Dan Pembelajaran.
Yuzarion, Y. (2017). Faktor Yang Mempengaruhi Prestasi Belajar Peserta Didik. Ilmu Pendidikan: Jurnal Kajian Teori Dan Praktik Kependidikan.

https://doi.org/10.17977/um027v2i12 017p107 